\title{
Pengaruh Model Pembelajaran Bermain Peran (Role Playing) terhadap Hasil Belajar Mata Pelajaran PPKn pada Materi Sumpah Pemuda dalam Bingkai Bhineka Tunggal Ika
}

\author{
Misbahudin* \\ STKIP Kusuma Negara, Indonesia
}

\begin{abstract}
Abstrak-Mata pelajaran Pendidikan Pancasila dan
Kewarganegaraan (PPKn) menjadi salah satu mata pelajaran yang memiliki tujuan untuk menumbuhkan nilai-nilai dan kebangsaan peserta didik selain juga untuk meningkatkan aspek pengetahuan yang diukur melalui hasil belajar. Namun, banyak peserta didik menganggap pelajaran PPKn tidak menarik dan membosankan. Tujuan penelitian ini adalah untuk mengetahui pengaruh pembelajaran bermain peran terhadap hasil beajar dan semangat kebangsaan siswa. Desain penelitian ini adalah pretest-postest one group design. Dalam desain ini, observasi dilakukan dua kali, yaitu sebelum dan sesudah eksperimen. Observasi yang dilakukan sebelum eksperimen disebut pretes dan observasi sesudah eksperimen disebut postes. Teknik pengumpulan data dilakukan dengan instrumen tes berbentuk pilihan ganda untuk mengetahui pengaruh pembelajaran bermain peran yang telah memenuhi uji validitas dan reliabilitas. Subjek penelitian adalah siswa SMP Karakter, Depok yang dipilih secara purposif sampling. Analisis data hasil belajar menggunakan uji-t untuk mengetahui ada tidaknya pengaruh model pembelajaran terhadap hasil belajar. Hasil penelitian menunjukan bahwa terdapat pengaruh positif model pembelajaran bermain peran terhadap hasil siswa dan semangat kebangsaan pada materi Sumpah Pemuda, mata
\end{abstract} pelajaran PPKn.

\author{
Kata kunci: \\ Bermain Peran, \\ Hasil Belajar, \\ Semangat Kebangsaan.
}

\section{Histori:}

Dikirim: 5 Maret 2021

Direvisi: 10 Maret 2021

Diterima: 14 Maret 2021

Online: 18 Maret 2021

\section{Identitas Artikel:}

Misbahudin, M. (2021). Pengaruh Model Pembelajaran Bermain Peran (Role Playing) terhadap Hasil Belajar Mata Pelajaran PPKn pada Materi Sumpah Pemuda dalam Bingkai Bhineka Tunggal Ika. Jurnal Citizenship Virtues, 1(1), 7-14.

\section{PENDAHULUAN}

Pendidikan Kewarganegaraan di tingkat dasar dan menengah mengalami perkembangan sejarah yang sangat panjang, dimulai dari Civic Education, Pendidikan Moral Pancasila, PPKn, pada Kurikulum 2004 berubah namanya menjadi mata pelajaran Pendidikan Kewarganegaraan, hingga kini pada kurikulum 2013 berubah menjadi PPKn. Tujuan dari pembelajaran PPKn selain juga untuk meningkatkan pengetahuan peserta didik tentang kebangsaaan, kewarganegaraan,

\footnotetext{
*Corresponding author

E-mail: misbahudin@stkipkusumanegara.ac.id
} 
moral pancasila, dan juga ketatanegaraan, juga untuk menanamkan nilai-nilai atau karakter kebangsaan yang berdasar Pancasila. Artinya, siswa yang sudah mengalami proses pembelajaran PPKn idealnya memiliki kompetensi kognitif yang baik yang dibuktikan dengan hasil belajar yang seringkali disimbolkan dengan angka-angka, dan juga memiliki sikap atau karakter yang baik. Hal ini sebagaimana menurut Winkel (1999), bahwa belajar adalah suatu aktivitas mental/psikis, yang berlangsung dalam interaksi aktif dengan lingkungan, yang menghasilkan perubahan-perubahan dalam pengetahuan, pemahaman, keterampilan, dan nilai serta sikap. Hal ini berarti bahwa proses pendidikan yang dialami oleh peserta didik salah satu tujuannya selain membuka pemaham juga penanaman nilai-nilai karakter, termasuk karakter kebangsaan.

Meski mata pelajaran PPKn teramat penting, namun tidak sedikit peserta didik yang menganggap bahwa mata pelajaran PPKn sebagai pelajaran yang membosankan. Selain itu, banyaknya bagian-bagian materi yang terkadang perlu dihafal karena akan terkait dengan hasil belajar seringkali membuat nilai siswa menjadi rendah karena harus menghafal dan memahami dalam kondisi bosan. Oleh karena itu perlu dilakukan pendekatan, strategi, atau Model pembelajaran yang kreatif. Salah satu pendekatan pembelajaran kreatif yang cocok untuk mata pelajaran PPKn adalah bermain peran (Jehaut, Harini \& Ayuningrum, 2020; Yenti, Asri \& Oktaviany, 2020).

Menurut Mulyono (2012), model role playing atau bermain peran adalah Model pembelajaran yang diarahkan untuk mengkreasi peristiwa sejarah, peristiwa aktual, atau kejadian-kejadian yang mungkin muncul pada masa mendatang. Sementara itu, menurut Wahab (2009), bermain peran adalah berakting sesuai dengan peran yang telah ditentukan terlebih dahulu untuk tujuan-tujuan tertentu, sehingga menciptakan situasi belajar yang berdasarkan pada pengalaman dan menekankan dimensi tempat dan waktu sebagai bagian dari materi pelajaran. Menurut Huda (2013), model bermain peran adalah suatu penguasaan bahan pelajaran melalui pengembangan imajinasi dan penghayatan peserta didik yang dilakukan dengan memerankan diri sebagai tokoh hidup atau benda mati. Model pembelajaran bermain peran melibatkan seluruh aspek indra peserta didik (Nadar, 2018). Peserta didik secara aktif melakukan bermacam praktek gerak, interaksi, komunikasi, dan berbahasa.

Dari berbagai pendapat di atas kita bisa menarik kesimpulan bahwa model bermain peran bisa menjadi salah satu alternatif model pembelajaran untuk mata pelajaran PPKn karena cenderung berhubungan dengan kronologi, dinamika, dan tempat dari suatu peristiwa yang terjadi dalam sejarah. Penelitian ini bertujuan untuk mengetahui pengaruh model pembelajaran pembelajaran bermain peran terhadap hasil belajar siswa dan semangat kebangsaan siswa pada materi Sumpah Pemuda Tahun 1928 dalam Bingkai Bhineka Tunggal Ika.

Dengan pembelajaran bermain peran, diharapkan pemahaman siswa terhadap materi menjadi lebih utuh. Siswa semakin mudah mengingat materi yang dibahas karena siswa seolah mengalami langsung peristiwa dengan melibatkan seluruh indera secara aktif. Dengan demikian akan juga meningkatkan hasil belajar siswa. Hasil belajar adalah prestasi dari suatu kegiatan yang telah dikerjakan, diciptakan, baik secara individu maupun tim (Djamarah \& Zain, 2007).

Model bermain peran sangat tepat diterapkan pada mata pelajaran PPKn karena pada materi pelajaran tersebut lebih banyak menekankan pentingnya pengamalan. Selain itu, pada mata pelajaran PPKn juga banyak bermuatan peristiwa sejarah 
sehingga melalui bermain peran, peserta didik seolah sedang merekonstruksi peristiwa tersebut dan mengalaminya secara langsung. Hal ini sesuai dengan yang diungkapkan Nirmayani (2020) bahwa tujuan bermain peran antara lain agar siswa dapat memahami perasaan orang lain, menempatkan diri dari situasi orang lain, dan mengerti dan menghargai perbedaan pendapat.

Banyak penelitian menunjukkan bahwa belajar dengan Model bermain peran sangat efektif untuk meningkatkan hasil belajar siswa karena berpusat pada diri siswa. Pembelajaran semacam ini juga melibatkan emosi karena siswa mengalami secara langsung melalui memerankan seorang tokoh dalam suatu peristiwa tertentu. Model pembelajaran bermain peran adalah model pembelajaran yang holistik karena melibatkan siswa secara utuh baik kognisi, psikomotorik, dan emosi dalam pembelajaran. Selain untuk meningkatkan hasil belajar, model pembelajaran semacam ini sangat cocok untuk diterapkan dalam rangka menanamkan semangat dan nilai-nilai kebangsaan kepada siswa. Model pembelajaran bermain peran terbukti dapat meningkatkan sikap nasionalisme atau semangat kebangsaan siswa siswa (Handayani, 2017).

Penanaman karakter semangat kebangsaan kepada siswa sebenarnya bisa dilakukan sepanjang mereka berada di seluruh lingkungan sekolah, tidak hanya di kelas. Namun demikian, pendidikan karakter kebangsaan juga bisa dilakukan dengan memberikan pelajaran secara khusus. Salah satu pelajaran yang terkait dengan penanaman karakter kebangsaan tersebut adalah mata pelajaran PPKn. Pendidikan kewarganegaraan diarahkan pada pembinaan sikap dan kemampuan bela negara. Berbeda dengan wajib militer yang mengedepankan aspek fisik, pendidikan kewarganegaraan ditekankan pada aspek kognitif dan afektif bela negara (Amin, 2010). Oleh karena itu, penelitian ini juga dilakukan untuk mengetahui bagaimana semangat kebangsaan siswa setelah mengikuti pembelajaran bermain peran melalui analisis angket.

Nilai semangat kebangsaan sendiri merupakan cara berpikir, bertindak dan wawasan yang menempatkan kepentingan bangsa dan negara di atas kepentingan diri dan kelompoknya. Sedangkan nilai cinta tanah air adalah cara berpikir,bersikap dan berbuat yang menunjukkan kesetiaan, kepedulian dan penghargaan yang tinggi terhadap bahasa, lingkungan fisik, sosial, budaya, ekonomi dan politik bangsanya (KEMDIKBUD, 2011).

Dalam penerapan pembelajaran bermain peran dalam penelitian ini, para siswa dari kelas 8 SMP Karakter Depok yang berjumlah 20 siswa memeragakan atau memerankan tokoh-tokoh perwakilan pemuda dari berbagai organisasi yang sedang melakukan Kongres Pemuda 1 dan 2. Materi Sumpah Pemuda dipilih karena peneliti menilai bahwa materi ini tepat karena menyertakan banyak orang sehingga tidak ada satupun siswa yang tidak ikut bermain peran.

Untuk mengetahui semangat kebangsaan siswa, setelah mengikuti pembelajaran, siswa diperintahkan mengisi angket yang berisi mengenai semangat kebangsaan.

\section{METODE PENELITIAN}

Penelitian ini dilakukan di SMP Karakter, Depok, dengan sampel kelas 8 Anggar. Metode yang digunakan dalam penelitian ini adalah quasi eksperimen. Adapun desain penelitian menggunakan pretest-postest one group design. Desain ini 
memungkinkan observasi dilakukan sebanyak dua kali yaitu sebelum eksperimen dan dan sesudah eksperimen. Observasi yang dilakukan sebelum eksperimen $\left(\mathrm{O}_{1}\right)$ disebut pretest dan observasi sesudah eksperimen $\left(\mathrm{O}_{2}\right)$ disebut posttest. Perbedaan antara $\mathrm{O}_{1}$ dan $\mathrm{O}_{2}$ adalah bahwa $\mathrm{O}_{1}-\mathrm{O}_{2}$ diasumsikan merupakan efek dari treatment atau eksperimen (Arikunto, 2005).

Untuk Desain penelitian dapat digambarkan sebagai berikut:

$$
\frac{\text { Pretest }}{\mathrm{O}_{1}} \frac{\text { Treatment }}{\mathrm{X}} \frac{\text { Post-test }}{\mathrm{O}_{2}}
$$

Keterangan :

$\mathrm{O}_{1}=$ sebelum diberikan perlakuan (treatment)

$\mathrm{X}=$ perlakuan (treatment)

$\mathrm{O}_{2}=$ setelah dilakukan treatment

Pengambilan data dalam penelitian ini menggunakan test dengan instrument test berbentuk soal pilihan ganda untuk menguji hasil belajar siswa. Selain itu, peneliti juga menggunakan questioner berupa angket untuk mengetahui pendapat siswa mengenai pembelajaran bermain peran. Angket dibuat dalam bentuk dua pilihan "Ya" dan "Tidak".

Sebelum instrument test digunakan, terlebih dahulu dilakukan diuji validitas dan reliabilitas. Uji validitas dilakukan menggunakan rumus $r$ product moment.

$$
r_{w}=\frac{N \sum(X Y)-\left(\sum X\right)\left(\sum Y\right)}{\sqrt{\left[N X^{2}-\left(\sum X\right)^{2}\left\lceil N Y^{2}-\left(\sum Y\right)^{2}\right]\right.}}
$$

dan diuji realibilitasnya menggunakan rumus Alpha sebagai berikut:

$$
r_{11}=\left(\frac{n}{n-1}\right)\left(1-\frac{\sum \sigma_{i}^{2}}{\sigma_{i}^{2}}\right)
$$

Dengan Klasifikasi interpretasi derajat reliabilitas suatu tes menurut Guilford (dalam Herlanti, 2008) berikut:

$$
\begin{array}{ll}
0,00-0,20 & \text { reliabilitas kecil } \\
0,20-0,40 & \text { reliabilitas rendah } \\
0,40-0,70 & \text { reliabilitas sedang } \\
0,70-0,90 & \text { reliabilitas tinggi } \\
0,90-1,00 & \text { reliabilitas sangat tinggi }
\end{array}
$$

Dari 20 soal yang dilakukan uji validitas, 16 soal dinyatakan valid.

\section{Analisis Data}

Analisis data dilakukan melalui uji hipotesis untuk menguji ada atau tidak pengaruh variable $\mathrm{X}$ terhadap Variabel Y. Uji hipotesis dilakukan melalui uji-t.

Sebelum dilakukan uji hipotesis, terlebih dahulu dilakukan uji prasyarat analisi dengan uji normalitas dan uji homogenitas. Uji normalitas dilakukan dengan uji Lilifors sedangkan uji homogenitas dilakukan menggunakan uji Fisher. 
Untuk mengetahui Analisis angket dilakukan dengan menggunakan rumus:

$$
P=\frac{f}{N} \times 100 \%
$$

Dengan:

$f=$ frekuensi yang sedang dicari presentasinya

$\mathrm{N}=$ Number of Cases (jumlah frekuensi/banyaknya individu)

\section{HASIL DAN PEMBAHASAN}

\section{Hasil Penelitian}

Sebelum diujikan, terlebih dahulu dilakukan uji validitas terhadap instrument tes. Dari 20 soal yang dilakukan uji validitas, 16 soal dinyatakan valid. Dari hasil uji normalitas, didapatkan perhitungan uji normalitas kelompok pretest adalah 0,188 dan hasil hitung uji normalitas kelompok posttest sebesar 0,187. Adapun nilai L table untuk jumlah sampel 20 adalah 0,190 Bila dibandingkan dengan L tabel, baik kelompok pretest maupun posttest lebih kecil dari pada L tabel.

Sesuai dengan kriteria yang ada yaitu $L_{\text {hitung }}<L_{\text {tabel }}=$ Ho diterima yang artinya data berdistribusi normal. Artinya baik pretest maupun posttest keduanya berdistribusi normal.

Tabel 2. Hasil Uji Normalitas Dengan Uji Liliefors

\begin{tabular}{ccccc}
\hline$\alpha$ & \multicolumn{2}{c}{$L_{\text {hitung }}$} & $L_{\text {tabel }}$ & Kesimpulan \\
\hline \multirow{2}{*}{0,05} & Pretest & Postest & \multirow{2}{*}{0,190} & $\begin{array}{c}\text { Berdistribusi } \\
\text { normal }\end{array}$ \\
\cline { 2 - 3 } & 0,188 & 0,187 & 0,18 & \\
\hline
\end{tabular}

Dari uji Homogenitas, didapatkan nilai sebagai berikut:

Tabel 3.Perhitungan Uji Homogenitas

\begin{tabular}{cccc}
\hline$\alpha$ & $F_{\text {hitung }}$ & $F_{\text {tabel }}$ & Keputusan \\
\hline 0,05 & 1,70 & 2,12 & Sampel homogen \\
\hline
\end{tabular}

Tabel 8 menunjukkan bahwa $F_{\text {hitung }}$ kurang dari $F_{\text {tabel }}$ yang berarti menunjukkan bahwa sampel homogen. Dengan data terdistribusi normal dan sampel homogen melalui uji statistik tersebut di atas, berarti memenuhi syarat untuk dilakukan uji hipotesis. Seperti sudah dijelaskan di awal, dalam uji hipotesis dalam penelitian ini digunakan uji- $t$.

Selanjutnya dari uji hipotesis dengan menggunakan uji- $t$, diperoleh $t_{\text {hitung }}$ sebesar 4,407. Adapun nilai $t_{\text {tabel }}$ pada taraf signifikansi 5\% adalah sebesar 2,086. Apabila dibandingkan, $t_{\text {hitung }}$ lebih dari $t_{\text {tabel }}$, dengan demikian hipotesis nol (Ho) yang menyatakan tidak ada pengaruh Model bermain peran ditolak. Dan hipotesis alternatif (Ha) yang menyatakan bahwa terdapat pengaruh model bermain peran dalam pembelajaran PPKn terhadap hasil belajar siswa diterima pada taraf signifikansi $5 \%$.

Untuk mengetahui efektivitas atau besarnya pengaruh variabel $\mathrm{X}$ terhadap $\mathrm{Y}$, dalam penelitian ini, dilakukan uji Normalitas Gain ( $N$-Gain) yang mengacu pada rumus Meltzer (dalam Herlanti, 2008) berikut. 


$$
N-\text { Gain }=\frac{\text { Skor Postes }- \text { Skor Pretes }}{\text { Skor Ideal }- \text { Skor Pretes }}
$$

Dari hasil perhitungan dengan rumus tersebut, didapatkan nilai hitung sebesar 0,457 atau dibulatkan menjadi 0,5 . Hal ini berarti pengaruh variabel $X$ terhadap $Y$ berada dalam kategori sedang.

Dari analisis angket yang dibuat dengan dua pilihan "Ya" atau "Tidak", 100\% siswa setuju bahwa pembelajaran bermain peran meningkatkan semangat kebangsaan.

\section{Pembahasan}

Dari hasil uji statistik di atas, didapatkan hasil bahwa pembelajaran bermain peran memiliki pengaruh cukup signifikan terhadap peningkatan hasil belajar siswa. Selain itu, dari hasil analisis angket yang disebar kepada sampel menunjukkan bahwa pembelajaran bermain peran dapat menumbuhkan semangat kebangsaan peserta didik. Hal ini karena mereka seolah merasakan peristiwa secara langsung saat memeragakan tokoh tertentu yang dalam hal ini para pemuda pelaku sejarah Kongres Pemuda yang menghasilkan sumpah pemuda.

Dari hasil temuan penelitian terlihat adanya perbedaan hasil tes atau nilai pretest dan nilai posttest. Hasil pretest menunjukkan bahwa pemahaman dan pengetahuan siswa terhadap materi sumpah pemuda masih sangat rendan. Rata-rata nilai pretes sebesar 65, 95. Ini tentu jauh dari KKM yang ditentukan untuk pelajaran PPKn yaitu 75,00 . Adapun nilai terendah pada pretest adalah 55 dan nilai tertingginya 75 . Sementara itu, nilai posttest siswa menunjukkan peningkatan dari nilai pretest. Pada nilai posttest, rata-rata nilai siswa adalah 79,25. Adapun nilai terendah dan tertingginya adalah 71 dan 90 . Temuan ini bisa menjadi petunjuk adanya indikasi pengaruh pembelajaran bermain peran terhadap hasil belajar siswa.

Indikasi adanya pengaruh positif pembelajaran bermain peran juga diperkuat oleh hasil uji hipotesis yang menunjukkan adanya pengaruh positif pembelajaran bermain peran terhadap hasil belajar siswa melalui uji t di atas. Selain itu, selama observasi yang dilakukan, siswa terlihat lebih antusias dan bersemangat dalam mengikuti pembelajaran dengan Model bermain peran ini.

Bermain peran sebagai sebuah model pembelajaran ternyata memiliki manfaat yang sangat besar dan efektif. Model tersebut tidak hanya dapat mengurangi bahkan mengubah kebosanan siswa dalam belajar menjadi semangat dan menyenangkan, tetapi juga dapat memudahkan siswa dalam mengingat materi yang sedang dibahas serta dapat meningkatkan hasil belajar siswa seperti yang telah dijelaskan di atas.

Mengenai respon siswa, peneliti juga menemukan ketertarikan siswa terhadap Model bermain peran. Dari pertanyaan-petanyaan pada angket yang peneliti sebar, hasilnya menunjukkan ketertarikan dan pendapat siswa terhadap Model bermain peran sangat positif. Dengan uji analisis persentase terhadap kuesioner tersebut, peneliti mendapatkan hasil bahwa persentase terbesar menunjukkan respon dan tanggapan positif siswa terhadap bermain peran dari pada pendapat negatifnya. Hal tersebut menunjukkan adanya pengaruh positif bermain peran terhadap hasil belajar dan semangat kebangsaan siswa.

Dari hasil jawaban siswa dalam mengisi angket, dapat disimpulkan bahwa siswa memberikan respon positif terhadap model pembelajaran bermain peran. Siswa 
juga sepakat bahwa semangat kebangsaan mereka meningkat. Bisa disimpulkan bahwa siswa menyukai pembelajaran bermain peran dan siswa setuju semangat kebangsaan mereka meningkat setelah mengikuti pembelajaran bermain peran ini.

Untuk materi pelajaran PPKn yang mengandung peristiwa sejarah, pembelajaran dengan bermain peran dapat meningkatkan semangat kebangsaan siswa.

\section{KESIMPULAN}

Dari pembahasan di atas, bisa ditarik kesimpulan bahwa pembelajaran dengan model bermain peran merupakan suatu model pembelajaran yang melibatkan seluruh indera peserta didik secara aktif. Pembelajaran tersebut melibatkan aspek gerak juga emosi peserta didik.

Hasil penelitian ini menunjukkan bahwa pembelajaran dengan model bermain peran terbukti bisa meningkatkan hasil belajar peserta didik. Karena dalam model pembelajaran bermain peran ini peserta didik terlibat aktif dalam memerankan tokoh dalam sejarah, membuat siswa mudah mengingat materi yang sedang diajarkan secara utuh. Pembelajaran ini melibatkan emosi peserta duduk untuk merasakan suatu peristiwa, sehingga dengan demikian diharapkan bisa menumbuhkan semangat kebangsaan peserta didik.

Hasil penelitian menunjukkan bahwa peserta didik memberi tanggapan positif terhadap model pembelajaran ini dimana mereka memberikan tanggapan bahwa pembelajaran bermain peran bisa menumbuhkan semangat kebangsaan mereka.

Pembelajaran bermain peran cocok untuk diterapkan untuk materi yang memiliki muatan pembahasan sejarah maupun peristiwa.

\section{REFERENSI}

Amin, Z. L. (2010). Pendidikan Kewarganegaraan. Universitas Terbuka.

Arikunto, S. (2005). Manajemen Penelitian. Jakarta: Rineka Cipta.

Djamarah, S. B., \& Zain, A. (2007). Strategi Belajar Mengajar. Jakarta: Rineka Cipta.

Handayani, T. (2017). Penerapan Metode Role Playing untuk Meningkatkan Kompetensi Belajar pada Mata Kuliah MSDM. Jurnal Utilitas, 3(1), 1-13.

Herlanti, Y. (2008). Tanya Jawab Seputar Penelitian Pendidikan Sains. Jakarta

Huda, M. (2013). Model-Model Pengajaran dan Pembelajaran.Yogyakarta: Pustaka Pelajar.

Jehaut, Y. A., Harini, H., \& Ayuningrum, S. (2020). Upaya Meningkatkan Motivasi Belajar PPKn pada Materi Sumpah Pemuda melalui Metode Role Playing. In Prosiding Seminar Nasional Pendidikan STKIP Kusuma Negara II (pp. 3643).

KEMDIKBUD. (2011). Pedoman pelaksanaan pendidikan karakter. Jakarta: Kementrian Pendidikan Nasional Badan Penelitian dan

Mulyono. (2012). Strategi Pembelajaran (Menuju Efektivitas Pembelajaran di Abad Global). Malang: UIN Maliki Press.

Nadar, W. (2018). Improving Spiritual Intelligence Through Role Play. Cakrawala

Dini: Jurnal Pendidikan Anak Usia Dini, 9(1), 44-50. 
Nirmayani, L. H. (2020). Peningkatan Kualitas Pembelajaran PKn di Sekolah Dasar Melalui Model Pengajaran Bermain Peran. Edukasi: Jurnal Pendidikan Dasar, 1(2), 207-215.

Wahab, A. A. (2007). Metode dan Model-Model Mengajar Ilmu Pengetahuan Sosial (IPS). Bandung: Alfabata.

Winkel, W. S. (1999). Psikologi Pengajaran, Jakarta: PT Grasindo.

Yenti, A. K. P., Asri, S. A., \& Oktaviany, V. (2020). Upaya Meningkatkan Motivasi Belajar Siswa dengan Menggunakan Metode Role Playing. In Prosiding Seminar Nasional Pendidikan STKIP Kusuma Negara II (pp. 179-183). 